\section{Bibliografia Consultada}

ADORNO, Sérgio. "Os Aprendizes do Poder: $O$ Bacharelismo Liberal na Política Brasileira." Rio de Janeiro, Paz e Terra, 1988

BANCAUD, A "Une constance mobile: la haute magistrature". In Actes du la Recherche en sciences sociales $\mathrm{n}$. 76-77-mars. 1989.

BARMAN, R \& BARMAN, J . "The Role of Law Graduate in the Political Elite of Imperial Brazil In "Journal of interamerican Studies and World Affairs, nov 1976. 18 (4) 423-50"

BOIGEOL, A. "La Formation des magistrats: De l'aprentissage sur le tas a l'école professionelle: In: Actes du le Rcherche en Sciences Sociales. $\mathrm{n}$ 76/77, mars. 1989.

BOEIRA, N. "O Rio Grande de Augusto Comte". IN DACANAL, J. H. e GONZAGA, S. (org) RS: $\mathrm{Cul}$ tura e Ideologia. Porto Alegre, Mercado Aberto, 1980.

BONI, Luis Alberto de Armando Câmara. Obrasescolhidas. Coleção pensadores gaúchos -1 . Porto Alegre, 1999. EDPUCRS.

BARRERAS, M. J. L. "Dario de Bitencourt (1901. 1974): Uma incursão pela cultura política autoritária gaúcha" Porto Alegre, EDIPUCRS, 1998.

BRANDALISE, C. "O Fascismo na Periferia Latino Americana: o paradoxo da implantação do integralismo no Rio Grande do Sul"'(dişa do de mestrado CPGCP-UFRGS), Porto Alegre, 1992. (mimeo)

COELHO, E. C. A profissões imperiais: Medicina, Engenharia e Advocacia no Rio de Janeiro(1822. 1930). Rio de Janeiro: Record, 1999

ENGELMANN, F. "A Formação da Elite jurídica no Rio Grande do Sul: Notas para uma pesquisa. IN Revista da Faculdade de Direito da Universidade Federal do Rio Grande do Sul, vol. 17, 1999

ENGELMANN, F. “A Formação da Elite jurídica no Rio Grande do Sul.(dissertação de mestrado) Porto Alegre, PPGCP-UFRGS, março 2001(mimeo)

FÉLIX, L.O. \& GRIJÓ, L. "Histórias de Vida: Entrevistase Depoimentos de Magistrados Gaúchos. Porto Alegre: Tribunal de Justiça do Estado do Rio Grande do Sul. Projeto Memória do Judiciário Gaúcho, 1999.

GRIJÓ, L. A "Origens sociais, estratégias de ascensão e recursos dos componentes da chamada 'geração de 1907'. (dissertação de mestrado). Porto Alegre, PPGCP-UFRGS, setembro de 1998
INSTITUTO DOS ADVOGADOS BRASILEIROS, História dos 150 anos do Instituto dos Advogados Brasileiros, ed Destaque-Rio de Janeiro, 1993

INSTITUTO DOS ADVOGADOS DO RIO GRANDE DO SUL; sessenta anos de existência, org. Antônio Paulo Cachapuz e Medeiros. Porto Alegre, IARGS, 1986.

LOVE, J. O regionalismo gaúcho, Perspectiva, 1975 MARCON, I.(org.) Poetas do Ministério Público Porto Alegre: AGE, 1996.

MARTINS, José Salgado. O Direito no Rio Grande do Sul. Porto Alegre, URGS, 1961

MELlo, Abdon de. "Ministério Público Riograndense"(subsídios para sua história), s/ed,

MENDONÇA, J. S. "Diálogos no solar dos Câmara" Coleção Pensadores gaúchos, EDIPUCRS Porto Alegre, 1999

NEQUETE, Lenine(org) $O$ Poder Judiciário no Rio Grande do Sul. Livro comemorativo do centenario do Tribunal da Relaça de Porto Alegre e Tri-

PINTO, C.R. "Positivismo - Um projeto político allernativo"(1889-1930)" Porto Alegre, LPM, 1986.

SANTOS, J. P. S. “A Faculdade de Direito de Porto Alegre" Porto Alegre: Síntese, 2000

SOARES, M. P. O positivismo no Brasil: 200 anos de Augusto Comte. Porto Alegre: AGE: Editora da Universidade, 1998

PANG, Eul Soo. \& SECHIRINGER, R. L "The Mandarins of Imperial Brazil" In: Comparative studies in society and history. University of Carolina - Press, mar 1972. 14(2):215-44

TILL, Rodrigues. História da Faculdade de Direito 1900-2000. Porto Alegre: Martins Livreiro, 2000

TRINDADE, F. C. "Uma contribuição à história da Faculdade de Filosofia da UFRGS. Revista do Instituto de Filosofia e Ciências Humanas, Porto Alegre, a X., p. 39-53, 1982

TRINDADE, F. C. "A Polêmica entre Érico Veríssimo e o Padre Leonardo Fritzen, S.J. Revista do Instituto de Filosofia e Ciências Humanas, Porto Alegre, 1984

\title{
A Aproximação das Legislações: o Caminho do Mercosul
}

\author{
Florisbal de Souza Del'Olmo \\ Professor convidado do Curso "O Novo Direito Internacional", \\ da Faculdade de Direito da UFRGS
}

\section{Introdução}

1 presente monografia busca realizar uma reflexão sobre a aproximação das legislações no âmbito do Mercado Comum do Su (MERCOSUL). É seu objetivo a identificação dessa aproximação e a apresentação de propostas que possam contribuir para uma integração mais efetiva no âmbito do bloco econômico regional.

A abordagem é efetuada a partir de noções de integração, blocos econômicos regionais e Direito Comunitário, detendo-se, por fim, na aproximação dos textos constitucionais do Estados-membros do Mercosul, capazes de propiciar a evolução do processo.

A investigação utiliza o método indutivo, comparativo e histórico, a contribuição do Direito Comunitário e a experiência da União Européia. Inúmeras obras, tanto nacionais quanto oriundas de outros países, constituem a bibliografia de que se serviu o pesquisador. As referências citadas ao longo do trabalho têm suas traduções para o vernáculo de responsabilidade do autor.

Compõe-se o ensaio de quatro capítulos: no primeiro se abordam os Movimentos de Integração, no que se entende indispensável para a compreensão do tema proposto, ocupando-se da União Européia, em cujo proces- so de constituição se buscam subsídios e reflexões no sentido de alcançar a aproximação das legislações nacionais dos Estados-partes do Mercosul. No segundo, é estudada a Integração no Cone Sul da América, reportando-se ao histórico e tratativas que redundaram na instituição do bloco. O terceiro capítulo se ocupa do Direito Comunitário e sua importância na consolidação do bloco econômico regional sulamericano, detendo-se ainda na instituição do futuro Tribunal de Justiça do Mercosul. O último capítulo estuda a Aproximação das Legislações dos Estados-partes.

Essa é a ênfase da investigação propriamente dita. Uma busca incessante com vistas ao encontro do conhecimento projetado, na expectativa de alcançá-lo. Sem dúvida, o ponto de partida é a integração, paradigma de um novo modo de viver democrático e harmônico entre Estados, objetivo dos povos do Mercosul.

Centra-se a monografia, por fim, no estudo da aproximação das legislações sobre a supranacionalidade nos quatro Estados do bloco regional do Cone Sul, buscando-se delinear a instituição, como proposta, de organismos comunitários capazes de completar o processo de integração e o desenvolvimento e a consolidação do Mercosul.

Revista da Faculdade de Direito da UFRGS, v. 20, Outubro/2001 
I. Os Movimentos de Integração

\subsection{Conceito de Integração}

Sem procurar definir o que seja integração, pensa-se buscar algumas luzes sobre esse fenômeno, que ocupa as atenções dos estudiosos dos mais importantes movimentos que envolvem o ser humano no dealbar do século XXI.

A integração é mais recente do que a própria globalização e se as pode entender ambas, mais como antagônicas do que como complementares. Admitindo-se que o mundo se venha a organizar em diversos blocos regionais, e que esses se transformem em comunidades, pode-se admitir em futuro não distante que a integração se constitua mesmo em uma parcela da globalização.

FERREIRA e OLIVEIRA definiram integração com rara propriedade: "É um processo de mudança social voluntária, mediante o qual, a partir da existência de problemas, interesses e objetivos comuns, as nações se associam e adotam estratégias de ação conjunta para melhorar seu status, o de suas respectivas comunidades, e sua inserção no sistema estratificado internacional"'.

Convém lembrar que para haver integração impõe-se que persistam diferenças entre os Estados engajados, cada um deles procurando na formação do bloco soluções para as suas deficiências.

\subsection{Pródromos dos Movimentos de Integração}

A idéia de um Estado global, no qual a população gozasse de direitos básicos e igualmente distribuídos entre todos, tem sido um sonho ao longo dos tempos. Mesmo os movi- mentos mais antagônicos, e aí poderiam ser citados o marxismo e o capitalismo, buscaram a unificação dos cidadãos sob um mesmo poder. Em essência, pregavam o domínio das pessoas por alguém, prometendo-lhes bem-estar e mehores condições de vida. Pecaram seus formuladores sempre, contudo, porque só os dominadores, de que são exemplo os mais férreos ditadores, como Stalin e Hitler, bem como os líderes do capitalismo, consideram-se em condições de ditar o paradigma de felicidade para seus subalternos. Günter GRASS, Prêmio Nobel de Literatura, observou: "O mundo capitalista somente está interessado em ganhar muito dinheiro da forma mais rápida possível. Assim como o comunismo, está destruindo seu próprio sistema porque acredita nas mentiras de sua própria propaganda"2.

O Império Romano no seu apogeu, a Idade Média sob Carlos Magno, a Grande França de Napoleão, o Reich Milenar de Hitler e o Planeta Soviético de Stalin, nos quais a voz de versal, foram, paradoxalmente, movimentos de integração.

Entretanto, é imperioso ressaltar que ditos movimentos não podem ser tidos como tal, na acepção contemporânea da palavra, na medida em que não foram, precipuamente, fruto da voluntariedade e do espírito democrático que hoje funcionam como o norte de qualquer espécie de integração entre Estados soberanos. Resultaram, em verdade, da imposição de determinados governantes, deturpando em alguns desses casos, manifestações oriundas da vontade popular. Deve-se enfatizar, com a devida clareza, que o significado atual do termo integração não comporta analogia com os movimentos referidos, ainda que, por linhas antagônicas, todos eles conduzam as populações chefes megalomaníacos era a suprema lei uni-

' FERREIRA, Maria Carmen e OLIVERA, Julio Ramos. Las relaciones laborales en el Mercosur, p. 10. ${ }^{2}$ GRASS, Günter. Não amor, mas tolerância, p. 4.

Revista da Faculdade de Direito da UFRGS, v. 20, Outubro/2001 envolvidas a um processo de aproximação e vivência sob um governo comum. A integração hoje provém de uma conscientização coletiva.

Impõe-se, ainda, reconhecer que tais tentativas aconteceram pela força e se alicerçavam na ambição e na vaidade desmesurada de conquistadores, interessados na subjugação das populações de todos os continentes, mas especialmente as européias, diversas em suas origens, culturas e idiomas, mas avançadas em seu desenvolvimento e habitando territórios com enormes potencialidades econômicas.

O princípio das nacionalidades de Mancini, pregado passionalmente em meados do século XIX, a partir de Turim, serviu de emblema e ponto de partida para as unificações italiana e alemã, que trouxeram no seu âmago o germe dos totalitarismos fascista e nazista, com funestas conseqüências no século seguinte.

Todos os movimentos enfocados, como se vê, tinham no horizonte o desejado domínio da população mundial por determinado segmento, pretendendo organizar o mundo em torno dos que tinham o privilégio de fazer parte do povo mais forte.

Até porque o vencido permanece na expectativa de uma desforra, todos esses processos chegaram ao seu ocaso, não deixando saudades, no conjunto da sociedade mundial, presentes os estigmas dessas experiências.

Cabe mencionar, ainda, o Cristianismo, que buscou a união, idealizando um mundo de pessoas irmanadas na vida em comunidade utopia de difícil compreensão ainda hoje. Todavia, o próprio Cristianismo foi enormemente influenciado pelos sonhos temporais de seus condutores, tendo muitos Papas se engajado na procura de conquistas territoriais e os Estados Pontifícios se envolvido em inúmeras guerras e na perseguição aos discordantes de sua linha ideológica, de que é triste exemplo o negro período da Inquisição.

\subsection{O Exemplo da União Européia}

A partir de meados do século XX, com destaque nas últimas décadas do milênio, integração entre Estados ou regiões se torna uma necessidade, em virtude dos avanços da tecnologia e das comunicações. O fenômeno se consolida gradativamente. Em um primeiro momento, isso ocorre sob o aspecto econômi$\mathrm{co}$, notadamente quanto às relações comerciais, mas com a expectativa de evoluir e atingir o social e o político, com evidentes vantagens para as populações envolvidas.

É impōssível falar-se na formação de blocos econômicos regionais sem analisar o mais arrojado modelo de integração, de unificação entre Estados soberanos, que é a União Européia, embora o mesmo ainda não esteja plenamente concluído.

Dedicado internacionalista, HUSEK enfatizou que "a civilização européia, berço do mundo moderno, é o resultado das instituições jurídicas e sociais romanas, do espólio helênico e do ideário judaico-cristão"3, exemplificado no seu individualismo radical ateniense, na impregnação da alma aristocrática romana nas leis, nas instituições e na paixão cristã pela justiça social.

Os meados da década de cinqüenta do século $\mathrm{XX}$ vão propiciar à humanidade assistir ao surgimento de um movimento de integração dos países europeus, após duas sangrentas guerras que envolveram, direta ou indiretamente, quase todos os povos do globo. E essa extraordinária busca de compreensão e entendimento começa com o engajamento das populações mais sacrificadas durante os dois conflitos mundiais: a francesa e a alemã.

São precisamente Alemanha e França, cada uma com cerca de dois milhões de morto na guerra de 1914-1918, derrotada e conquistada em seis semanas a segunda e literalmente aniquilada a primeira ao final da Segunda Guerra Mundial, que acordam a instituição da Comunidade Européia do Carvão e do Aço 
$(\mathrm{CECA})^{4}$. Enfatize-se que esses dois países possuíam estratégicas reservas carboníferas e de aço, mormente na região do Ruhr, na Alemanha, e da Lorena, na França. A aludida convenção, datada de 18 de abril de 1951 , e que passaria à História como o Tratado de Paris, teve como signatários, além dos países referidos, Itália, Bélgica, Holanda e Luxemburgo, esses três últimos já integrados entre si no bloco conhecido por BENELUX, criado em $1^{\circ}$ de janeiro de 1948.

Com objetividade, ROQUE observa que esses seis Estados haviam concluído que as duas grandes guerras tiveram como motivos primordiais "a produção, em excesso, de produtos siderúrgicos e a dificuldade de colocação desses produtos no mercado internacional, gerando litígios contínuos, até o desencadear da guerra"s.

Seria, contudo, uma trilogia de convenções que daria origem e consistência à magna tentativa de integração continental européia: Tratado Institutivo da Comunidade Econômica Européia (CEE), que passaria à História como o Tratado de Roma, assinado em 25 de março de 1957, na capital do antigo Império Romano, e o Tratado Institutivo da Comunidade Européia de Energia Atômica (CEEA), também acordado na mesma ocasião e tendo como signatários os Estados participantes já mencionados na Comu- nidade do Carvão e do Aço.

A moderna idéia de integração européia tem dois mentores, que devem ser citados: Jean Monnet, Chefe do Planejamento de Reconstrução e Modernização da França e Robert Schuman, Ministro das Relações Exteriores do mesmo país, nos últimos anos da década de 40 . Jean Monnet foi o idealizador da Comunidade em torno do tratamento em conjunto a ser dado às políticas do carvão e do aço, pois defendeu uma igualdade de direitos aos alemães, impensável até então, já que a Alemanha, dividida e ocupada, não dispunha de soberania plena. Robert Schuman, ao adotar o ideário de Jean Monnet, vai exercer extraordinário papel no futuro europeu, com sua ontológica declaração de 9 de maio de 1950, em Paris, transcrita em muitos estudos, inclusive por $S O D E R^{6}$

O movimento pela unificação do continente europeu teve sua culminância no Tratado de Maastricht, assinado em 1992, nessa cidade holandesa, perto da fronteira com a Bélgica, o qual transformou a Comunidade Econômica Européia em Comunidade Européia (CE), e as três Comunidades (do Carvão e do Aço, Econômica Européia e Européia de Energia Atômica) em União Européia, a qual se constitui, como acentuou VIANA SANTOS, na experiência "mais antiga, mais sofisticada e mais amadurecida que se conhece" .
${ }^{3}$ HUSEK, Carlos Roberto. Curso de direito internacional público, p. 134. Segundo esse autor, o Tratado de Roma, que foi assinado em 1957, é "talvez um dos fatos jurídicos mais importantes deste século e vem demonstrar que o Direito Internacional, como sistema, é possível desde que a cooperação supere o conceito de soberania”. Idem, p. 135.

${ }^{4}$ Joana Stelzer identificou a CECA como a "primeira resposta positiva de integração européia e pedra fundamental de todo o edifício comunitário". STELZER, Joana. Integração européia: dimensão supranacional, p. 71.

${ }^{5}$ ROQUE, Sebastião José. Direito internacional público, p. 111-112. O autor destaca que a própria produção seria explorada em comum, devendo cada país produzir apenas o suficiente para suprir o mercado comum, evitando concorrência desnecessária entre si.

${ }^{6}$ SODER, José. A União Européia, p. 29. Para esse autor, a declaração de Robert Schuman é tida como a certidão de nascimento da Comunidade Européia.

7 VIANA SANTOS, Antônio Carlos. Tribunal de justiça supranacional do Mercosul, p. 26.

Revista da Faculdade de Direito da UFRGS, v. 20, Outubro/2001
Por fim, em 2 de outubro de 1997 é assinado o Tratado de Amsterdã, pelo qual se modificam substanciais postulados em diversos artigos dos Tratados da década de 50 , instituidores das três anteriores Comunidades. Palmilha-se, assim, o caminho natural que a integração vai ensejando, adaptando-o às novas circunstâncias e preparando-o para as necessidades e desafios futuros do poderoso bloco europeu.

\section{A Integração chega ao Cone Sul da América}

\subsection{Sonho Antigo}

Caso se busquem as origens da história de aproximações e desencontros dos povos que formam o Mercado Comum do Sul, Mercosul, remontar-se-á à última década do século $\mathrm{XV}$ quando, em 1493 e 1494, com a Bula Inter Coetera, do Papa Alexandre VI, e com o Tratado de Tordesilhas, firmados por portugueses e espanhóis, foram divididas as terras do continente americano, cabendo a Portugal as que ficassem cem (no primeiro desses documentos) e trezentas e setenta léguas (no último), a leste das Ilhas do Cabo Verde. As situadas a oeste dessa linha imaginária seriam espanholas.

Foram tratados concertados entre as duas maiores potências da época, que delinearam os domínios de povos europeus sobre as pouco habitadas terras americanas, nas quais 0 estágio de vida das populações e seus limitados recursos bélicos não habilitavam seus nativos a fazerem frente à colonização que se en cetaria, às expensas de trágicos sofrimentos da destruição de culturas, constituindo-se em um dos mais nefandos genocídios da história humana.

Há que referir também as diferentes for- mas e princípios de colonização utilizados nos dois hemisférios do continente americano: os ingleses, no Norte, com a vinda, desde o início do processo de ocupação das terras, de pessoas interessadas em se fixar e realizar um plano de vida no novo mundo, explorando a terra em benefício próprio; e os espanhóis e portugueses, no Sul, com expedições essencialmente exploradoras, que buscavam ouro e outras riquezas minerais, que acabariam por fazer a opulência de templos e palácios europeus, em detrimento da terra e dos seus naturais.

O triste saldo da destruição das culturas inca, no Peru, e asteca, no México, são consectários dessa postura espanhola, essencialmente realizada, no início, por aventureiros, unicamente interessados no bem-estar e enriquecimento pessoais e no de seus senhores: os monarcas europeus e suas insaciáveis cortes.

\subsection{A Integração a Partir do Século XIX}

Dois homens nascidos na América, que viveram no século XIX, Simão Bolívar e José de San Martin, dedicaram suas existências à busca da unificação dos povos latino-americanos. Tratados, projetos de união e sonhos de confederação por eles intentados conseguem legar à posteridade tão somente as sementes de uma integração que só floresceria século e meio depois.

Antecedentes do Mercosul, já no século XX, foram a Associação Latino-Americana de Livre Comércio (ALALC) e a Associação Latino-Americana de Integração (ALADI), criadas ambas por Tratados assinados em Montevidéu, respectivamente em 1960 e 1980 , sendo a segunda uma sucessora da primeira, que não atingira os objetivos almejados, como refere FARRANDO $O^{8}$ e como têm sido lembrados pela maioria dos autores que abordam os pródromos 
do bloco regional do Cone Sul da América ${ }^{9}$.

\subsection{Brasil e Argentina: Mais Perto do Merca- do Comum}

Atendo-se mais especificamente à concepção e à institucionalização do Mercosul, impõe-se referir o relacionamento entre os dois maiores países sul-americanos: Brasil e Argentina. É que, se a União Européia foi concebida a partir do concerto franco-alemão, o Mercosul só começou a se tornar realidade graças ao entendimento brasileiro-argentino.

Já observou RECKZIEGEL que a característica principal desse relacionamento, "mesmo que intercalado por momentos de amizade, ou até mesmo de certa indiferença, foi o constante estado de rivalidade. Muitas vezes não oficialmente declarado, o antagonismo permeou essas ligações na medida em que suscitou desconfianças e prevenções mútuas" 10 . Segundo a autora, "esse contexto de rivalidade foi animado, antes de qualquer coisa, pela pretensão de ambos de liderarem as nações do bloco sulamericano, ou seja, pelo desejo de hegemonia regional." "11

Se as divergências entre os dois gigantes do Cone Sul da América datam de mais de

- Ver: ALMEDA. ElzahethAcciov Pinto

9 Ver: ALMEIDA, Elizabeth Accioly Pinto de. Mercosul \& União Européia: estrutura jurídico-institucional, p.19. ALMEIDA, Paulo Roberto de. O Mercosul no contexto regional e internacional, p. 64-68. BASALDÚA,
Ricardo Xavier. Mercosur y derecho de integración, p. 65-74. DEL'OLMO, Florisbal de Souza. Direito internacional privado: abordagens fundamentais, legislą̧ãa, jurisprudência, p. 149-166. ESTRELLA FARIA Ângelo. O Mercosul: princípios, finalidade e alcance do Tratado de Assuncão, p. xv. HUSEK C FARIA, Jose 129-130. MIDÓN, Mario A. R. Derecho de la integración, p. 283-296. ROQUE, S. JUSEK, C. R. Op. cit., p. Roberto Lui Direito comunitário da de la integración, p. 283-296. ROQUE, S. J. Op. cit., p. 173. SILVA Roberto Luiz. Direito comunitário e da integração, p. 111-115. SOARES, Esther Bueno. Mercosul: desenvolvi-
mento histórico, p. 19-22.

${ }^{10}$ RECKZIEGEL, Ana Luiza Gobbi Setti. O pacto ABC: as relações Brasil-Argentina na década de 50, p. 30 Esse trabalho é o resultado de pesquisa, como dissertação de mestrado, aprovada na PUC de Porto Alegre, RS. O pacto $\mathrm{ABC}$ - de Argentina, Brasil e Chile - "a despeito de sua fachada integracionista, evidenciou a histórica disputa pela liderança do bloco sul-americano entre as duas nações", conclui a mestra da Universidade de Passo Fundo. Idem, p. 167.

${ }^{11}$ Idem, ibidem.

${ }^{12}$ BASALDÚA, R. X. Op. cit., p. 65.

Revista da Faculdade de Direito da UFRGS, v. 20, Outubro/2001
As dificuldades enfrentadas por Brasil e Argentina nas últimas três décadas, tanto no plano interno - em que abundavam problemas distintos, inclusive longos períodos de gover nos ditatoriais -, quanto no contexto internacional, com graves conseqüências para seus povos, serviram, paradoxalmente, para convencêlos da necessidade de aproximação, de enten dimento, e, em última análise, de integração.

Sobre a transcendental importância da aproximação entre os dois maiores Estados sulamericanos, observou ALMEIDA, com propriedade,: "A opção política fundamental - propriamente geopolítica, no bom sentido da palavra - feita pelas lideranças políticas de ambos os países, no sentido de encerrar décadas de egoísmos nacionais estreitamente mesquinhos erivalidades hegemonistas de origem supostamente castrense, para inaugurar uma nova era de concórdia e de orientação política e econômica no relacionamento bilateral, constitui provavelmente o elemento mais significativo da história da região neste último meio século"13 .

E o resultado foi o surgimento do Mercosul. Emblematicamente, o primeiro passo efetivo na consecução desse objetivo ocorreu na mesma região de Itaipu, com a Declaração de Iguaçu, assinada em 30 de novembro de 1985 pelos presidentes da Argentina e do Brasil, expressando a determinação de se aproximarem política e comercialmente os dois países, superando antigas e, lamentavelmente, tradicionais rivalidades.

Tal fato ocorreu quando se inaugurava a Ponte Presidente Tancredo Neves, unindo Puerto Iguazu, na Argentina, a Foz do Iguaçu, no Brasil. Um elo físico-geográfico sobre um grande rio, tão caro este a ambos os países,

\section{${ }^{13}$ ALMEIDA, P. R. Op. cit., p. 72.}

${ }^{14}$ OLIVEIRA, Odete Maria de. Integração nuclear Brasil-Argentina: uma estratégia compartilhada. Ver também: OLIVEIRA, Odete Maria de. A integração bilateral Brasil-Argentina: tecnologia nuclear e Mercosul, p. 523. serviu de campo para estreitar os vínculos histórico-espirituais entre os dois povos, até então separados por um imenso caudal de desencontros, ambigüidades e desconfianças entre seus governantes, mas atavicamente unidos pela origem latina e ibérica comum.

Também aí se firmou a Declaração Conjunta sobre Política Nuclear, início da camiA busca da harmonização na política argentino-brasileira sobre energia nuclear tem merecido acurados estudos de $O L I V E I R A^{14}$, vindo a lume trabalhos que permitem amplo conhecimento do tema e de suas benfazejas conseqüências para ambos os países e para a tranqüilidade de seus povos.

\subsection{Nasce o Mercosul: Tratado de Assunção}

Os pactos mencionados têm sequiência em 1986, com a Ata para a Integração BrasilArgentina e, em 1988, com o Tratado de Integração, Cooperação e Desenvolvimento, nesse já se estabelecendo uma área econômica comum e definindo-se, inclusive, um horizonte temporal: dez anos. Por fim, em julho de 1990 assina-se a Ata de Buenos Aires, pela qual os presidentes dos dois países decidiram instituir um mercado comum bilateral até o final de 1994. Nunca é demais enfatizar: tudo isso ocorreu sul-americanos.

Todas essas meritórias tratativas tiveram ampla repercussão na imprensa continental e foram percebidas pelos demais países da região, o que levou o Uruguai, inicialmente, e logo após o Paraguai a manifestarem a intenção de se integrar ao nascente organismo, cujo esnhada de cooperação nesse delicado terreno. envolvendo apenas os dois maiores Estados 
boço tomava corpo. Estava preparado o terreno para o surgimento daquele que se vai tornando promissor modelo de integração econômica de países da América do Sul, lastreado pela experiência registrada na União Européia.

O Mercado Comum do Sul (Mercosul), constituído formalmente pelo Tratado de Assunção, assinado na capital guarani no dia 26 de março de 1991, tem como seus componentes originários o Brasil, a Argentina, o Uruguai e o Paraguai, mas registrando-se o interesse manifestado por outros países da região na futura integração. Entre esses devem ser destacados o Chile e a Bolívia, já participando do bloco regional desde 1996, na condição de associados.

Enfatiza MIDÓN que uma observação retrospectiva sobre a busca de integração empreendida pelos diversos países americanos leva o estudioso a concluir que as experiências havidas, a par de terem sido inicialmente políticas e econômicas, transformaram os processos de integração, tal como hoje vêm sendo concebidos, não mais em projeto político de determinado governo, mas em política de Estado, reafirmada de modo regular e periódico, e agindo como instrumento de desenvolvimento dos respectivos povos, verificando-se acentuada interdependência entre os partidários de cada processo, o que conduz ao entendimento de que o caminho para levar adiante o empreendimento é o do regionalismo aberto ${ }^{15}$.

O Tratado de Assunção representa o nascimento do Mercosul na esfera do Direito Internacional: a partir desse histórico documento um novo bloco econômico regional passa a se constituir como uma célula expressiva da Sociedade Universal. Esse acordo emblemático coloca a emergente associação de Estados no contexto do Direito das Gentes, ainda que um tratado posterior, o Protocolo de Ouro Preto, de

17 de dezembro de 1994, seja o marco formal da instauração do bloco no mundo das ciências jurídicas, uma vez que foi a partir de então, segundo o art. 34 desse Protocolo, que o Mercosul passaria a ter personalidade jurídica.

Embora seja um acordo de caráter eminentemente econômico, o Tratado de Assunção não pode a esse aspecto ser reduzido, devendo, a serem seguidos os seus preceitos, buscar-se incessantemente a melhora da proteção social e do nível de vida dos cidadãos e estabelecidas suas liberdades, até porque, no seu artigo primeiro, está preconizada a livre circulação de bens, de serviços e de fatores produtivos entre os países.

\section{O Direito Comunitário e o Mercosul}

\subsection{Considerações Iniciais}

O sucesso da integração de Estados soberanos, muito bem representado pela União Européia, ensejou, com a pertinente consolidação do espírito de comunidade, o desenvolvimento do Direito Comunitário. Trata-se de disciplina jurídica própria, distinta da ordem jurídica interna e da internacional.

VIGNALI, renomado Professor de Direito e Doutor em Diplomacia uruguaio, entende o Direito Comunitário como "o conjunto de normas jurídicas e princípios que as hierarquizam e coordenam coerentemente, que regula as relações entre Estados soberanos e Organizações Internacionais que participam de um processo de integração amplo e profundo, quando atuam (as normas e princípios) nos limites de uma comunidade internacional inserida em uma sociedade maior, com o propósito de cooperar com os Estados-membros, sob a coordenação da
Organização que os agrupa, para obter maio segurança e bem-estar e fortalecer suas posições ao atuarem (essas organizações) em conjunto frente aos demais Estados."16

A rigor, essa ordem jurídica só exercerá seu importante papel no contexto dos povo mediante cedência de parcela da soberania dos Estados, o que tem ocorrido através dos Tratados entre os países engajados no processo. E imprescindível que se entenda que é justamente a soberania (que não se perde) que viabilizará uma projetada integração: a soberania atribui ao Estado o poder de decidir se irá ou não participar de um bloco regional.

É pressuposto do Direito Comunitário a adoção, pelos países engajados no processo de integração, do instituto da supranacionalidade. Deve ser desprezado o entendimento equivocado de que soberania supranacionalidade são incompatíveis, mito que necessita ser afastado, uma vez que a integração plena pode e deve ocorrer sem que os Estados abram mão de sua soberania.

Quanto ao direito interno, difere ele da ordem jurídica comunitária por disporem os tribunais comunitários de competências específicas, embora o objeto substancial desse direito sejam atos e fatos que têm seu curso no território dos Estados-membros.

Na expressão de RULLI JUNIOR, “o direito comunitário não se opõe ao direito nacional, porque não o derroga expressa ou tacitamente, não havendo hierarquia entre eles, apenas prevalência da regra comunitária." ${ }^{17}$ Embora se entenda que hierarquia e prevalência são

\footnotetext{
${ }^{16}$ VIGNALI, Heber Arbuet. Soberanía e integración, p. 102-103.
}

${ }^{17}$ RULLI JUNIOR, Antonio. Mercosul: o direito comunitário e a garantia de investimentos e cidadania, p. 63 64.

${ }^{18}$ LOBO, Maria Teresa Cárcomo. Ordenamento jurídico comunitário: União Européia-Mercosul, p. 43. ${ }^{19}$ FERREIRA, M. C. e OLIVERA, J. R. Op. cit., p. 103.

Revista da Faculdade de Direito da UFRGS, v. 20, Outubro/2001 sinônimos, a observação desse autor identifica algo que deve restar claro: a norma comunitária prevalece quando oposta à interna.

Observou $\angle O B O$ : "A autonomia do direito comunitário não o impede de estar integrado nas ordens jurídicas internas, uma vez que as suas diferentes regras tomam lugar no seio dos ordenamentos nacionais, aí se aplicando diretamente e prevalecendo sobre as regras nacionais contrárias." 18

A doutrina tem apresentado como características do Direito Comunitário a aplicabilidade imediata (suas normas adquiro), a aplicabilidade direta (cria direitos e obrigações por si mesmo) e a prevalência (a norma dos países integrantes da Comunidade) ${ }^{19}$.

\subsection{O Direito Comunitário e o Direito Inter-} nacional

A diferença essencial entre o ordenamento comunitário e o internacional consiste em que este não se impõe à ordem jurídica dos Estados, não existindo, como se sabe, uma ascendência jurídica dos tribunais internacionais sobre as cortes nacionais, até porque não existe um órgão institucionalizado com essa competência, o que seria, diga-se, uma hipotética Suprema Corte Planetária. Já em relação ao cão sui generis, uma subordinação das ordens jurídicas internas ao Tribunal Comunitário Supranacional, quando este vier a existir.

${ }^{15}$ MIDÓN, M. A. R. Op. cit., p. 33

Revista da Faculdade de Direito da UFRGS, v. 20, Outubro/2001 
$\mathrm{Na}$ esteira da observação de $W O L K M E R^{20}$ de que existe forte legalismo de cunho nacional-monista e histórica tradição do Estado como fonte privilegiada de produção legislativa nos países latino-americanos, capazes de dificultar o Direito Comunitário na região, pode-se enfatizar que é indiscutível a prevalência do direito interno sobre a norma jurídica internacional nos Estados-membros do Mercosul. É peremptório que o ordenamento jurídico de cada um desses países é monista com primazia do direito nacional.

Sem querer abordar em profundidade as teorias que estudam as relações entre os ramos do Direito, monista e dualista, não seria demasiado observar que a implantação do Direito Comunitário nesses países poderia ocasionar uma despropositada terceira teoria nas relaçõe entre os campos das ciências jurídicas, triadicalismo, consistente em uma ordem jurídica que comportaria três sistemas paralelos: 0 direito interno, o internacional e o comunitário, com presumível predomínio do direito nacional, o que dificultaria a aplicação eficaz da legislação emanante da Comunidade.

O Direito Comunitário está sincronizado com o espírito da nova ótica da integração do Direito Internacional. Caminha-se hoje em direção a um mundo integrado, ou um mundo globalizado, no qual o ser humano está irreversivelmente se engajando, de uma forma ou de outra, a um modo de vida universal.

\subsection{O Direito Comunitário no Mercosul: Uma Necessidade}

No âmbito da União Européia a primazia

do Direito Comunitário se verifica, e não poderia ser diferente, mesmo sobre as próprias normas constitucionais dos países da Comunida$\mathrm{de}^{21}$. Assim, se o juiz, no curso de um processo, se defronta com uma contradição entre a norma jurídica interna e a norma do Direito Comunitário, deverá optar pela aplicação dessa última. Fruto da jurisprudência comunitária, a prevalência sobre o direito interno vem sendo reiteradamente aplicada na União Européia, constituindo em paradigma para o futuro Direito Comunitário no Cone Sul da América.

Trazendo para o Mercosul o exemplo europeu, no que for adequado, são relevantes as considerações de BERTOLOTTI - após lembrar que longo ainda é o caminho que deve ser percorrido pelo bloco regional sul-americano no terreno jurídico e institucional - quando afirma: "Esse fenômeno não é só produto da história, mas também criação do direito. Um direito que deu vida e que deve permitir agora seu desenvolvimento e seu crescimento, pois - tal como sucedeu na Comunidade Européia - é um efetivo fator integrador, capaz de fazer do Mercosul uma verdadeira "comunidade de direito."22

No caso do Mercosul, o Direito Comunitário originário se encontra no Tratado de Assunção e no Protocolo de Ouro Preto, que poderiam, na esteira do entendimento de José Soder, antes mencionado, serem considerados como a Constituição escrita do Mercosul.

Verifica-se, por outro lado, que o Direito Comunitário derivado emana de órgãos constitutivos dos blocos econômicos regionais, como o Conselho, o Grupo e a Comissão de Comércio, no caso do bloco econômico regional do Cone Sul. Esses organismos foram cria-

${ }^{20}$ WOLKMER, Antônio Carlos. Integração e direito comunitário latino-americano, p. 48.

${ }^{21}$ Charles Vallée, ao recordar que as Constituições da maioria dos Estados que formam a União Européia préexistiam às Comunidades, enfatiza que algumas delas sofreram revisões a fim de se adaptarem ao ordenamento jurídico comunitário. VALLEE, Charles. $O$ direito das comunidades européias, p. 105.

${ }^{22}$ BERTOLOTTI, Silvina Barón Knoll de. Administración y gobierno del Mercosur, p. 175.

Revista da Faculdade de Direito da UFRGS, v. 20, Outubro/2001 dos nos Tratados instituidores das Comunidades, e entre suas atividades está previsto o estabelecimento dessas normas.

O artigo 42 do Protocolo de Ouro Preto estabelece que as normas emanadas dos órgãos do Mercosul, previstos no seu artigo $2^{\circ}$, quais sejam o Conselho do Mercado Comum, o Grupo Mercado Comum e a Comissão de Comércio do Mercosul, terão caráter obrigatório e deverão ser incorporadas aos ordenamentos jurídicos nacionais dos Estados-membros quando necessário, mediante procedimentos previstos na legislação de cada um deles.

Há que ressaltar que, pelo artigo 38 do mesmo Protocolo, os países do bloco regional mercosulista ficam comprometidos a adotar as medidas necessárias para assegurar o cumprimento, no território respectivo, das normas provenientes dos órgãos do Mercosul, normas as quais estão previstas no mencionado artigo $2^{\circ}$ do documento de Ouro Preto. E para garantir a vigência simultânea de tais normas nos Estados-membros deverão ser adotadas as medidas necessárias à sua incorporação ao ordenamento jurídico nacional, comunicadas Secretaria Administrativa do Mercosul.

Por ora, a consolidação de um Direito Comunitário no bloco econômico regional do Cone Sul está longe de se tornar uma realidade. Afirmuu BAHIA que "o direito comunitário do Mercosul, quanto à aplicabilidade direta, possui uma característica invulgar, por merecer distinto apreço por parte dos Estados-partes do acordo. Para uns, pode tratar-se de autêntico direito comunitário (supranacional). Para outros, não passaria de direito internacional puro e simples"23.

Torna-se imperiosa, para a consolidação do Mercosul e a consecução dos seus objetivos, a implantação, em seu âmbito, do Direito

${ }^{23}$ BAHIA, Saulo José Casali. A supranacionalidade no Mercosul, p. 195

${ }^{24}$ BERTOLOTTI, S. B. K. Op. cit., p. 145-152.

Revista da Faculdade de Direito da UFRGS, v. 20, Outubro/2001
Comunitário. E ela só ocorrerá quando os Estados participantes, cônscios da magnitude do momento que atravessam, adotarem como instituição do grupo a supranacionalidade. Será o abandono da integração intergovernamental, que depende da unanimidade, sempre mais difícil ante assuntos muitas vezes polêmicos, até porque os interesses regionais podem ser divergentes ou antagônicos, em favor da decisão partida da comunidade, que é soberana na sua determinação e procede de um consenso.

\subsection{O Futuro Tribunal de Justiça do Mercosul}

Ao analisar a estrutura institucional do Mercosul-depois de referidas as experiências comunitárias para o bloco regional sul-americano, representadas pela União Européia BERTOLOTTI assinala, entre outros, os seguintes importantes aspectos: 1) natureza intergovernamental de todos os órgãos instituídos, ausente, portanto, a supranacionalidade; 2) a inexistência, na atual estrutura do Mercosul, de um órgão que represente exclusivamente os te a respeito dos Estados-partes; 3) a falta de uma clara distinção de funções entre os órgãos atuais, embora o avanço trazido, nesse sentido, pelo Protocolo de Ouro Preto; 4) a inexistência de uma instituição que represente os povos dos Estados, permitindo-lhes participar no processo de elaboração normativa, qual fosse um Congresso, um Parlamento ou uma Assembléia; 5) ausência de um Tribunal de Justiça do Mercosul, o que impossibilita a uniformidade de interpretação e aplicação dos termos do Tratado de Assunção e do direito dele derivado; e 6) o estado de indefesa no procedimento previsto para as reclamações dos particulares, já que ausente norma que dirima a aplicação de medida de efeito restritivo ou discriminatório ${ }^{24}$. interesses comunitários, que seja independen- 
ALMEIDA enfatiza: "Um dos grandes problemas da evolução política futura do Mercosul é, precisamente, o 'salto' para a adoção integral de instituições comunitárias de tipo supranacional, transição que ocorrerá, mais cedo ou mais tarde, nos países-membros, considerando-se que o Mercosul constitui, efetivamente, o embrião de etapas superiores de integração" 25 .

Para STELZER, "a origem da supranacionalidade encontra-se na transferência de parcelas soberanas por parte dos Estados-nacionais em benefício de um organismo que, ao fusionar as partes recebidas, avoca-se desse poder e opera por cima das unidades que o compõem, na qualidade de titular absoluto." 26 Já COSTA entende que a supranacionalidade está "ligada à legitimidade regional e apenas tem sentido quando é instrumento das demandas sociais, notadamente a de integração. A opção por órgãos e direitos supranacionais não é, assim, uma questão de mera vontade, mas principalmente de finalidades e possibilidades sociais. Deve, portanto, estar balizada por uma análise profunda da sociedade e da economia, mas nunca pode lançar suas bases sobre modelos formais, cujo transplante apenas pode resultar em rejeição."27

A importância fundamental da implantação do Direito Comunitário no bloco regional do Cone Sul da América é uma imposição realçada por RULLI JUNIOR, que acrescenta dever ele ser construído "com a participação e

o compromisso da sociedade civil da região, seus governos e estruturas governamentais e políticas, aplicado por uma Corte de Justiça, também regional e independente, que possibilitará a construção e a conseqüente manutenção de regras jurídicas claras, e com efetividade social compatível com as necessidades"28

Ainda sobre a institucionalização de um Tribunal de Justiça em uma comunidade de Estados, acompanhe-se ALMEIDA: "A existência de um Tribunal da Justiça é um elemento essencial num processo de integração. $O$ sistema de repartição das competências que ele comporta supõe a garantia para os Estados de que o seu respeito será assegurado tanto por parte das instituições como dos seus membros. A subordinação a regras comuns implica que a uniformidade da sua aplicação será mantida, pois, se numa comunidade de Estados as normas comunitárias estivessem sob o controle dos tribunais nacionais, elas seriam interpretadas $\mathrm{e}$ aplicadas diferentemente em cada um deles. A aplicação uniforme do Direito Comunitário seria, por conseqüência, posta em causa." ${ }^{29}$

CAIROLIMARTINEZ enfatiza sua convicção de que a criação de um tribunal de justiça "será suficiente garantia da segurança jurídica que deve emanar da jurisprudência, o que contribuirá para a segurança de toda a população dos países que integram a comunidade." ${ }^{30}$ Para ele, somente o futuro Tribunal de Justiça do Mercosul garantirá a aplicação uniforme do Direito Comunitário.

${ }^{25}$ ALMEIDA, Paulo Roberto. O Mercosul no contexto global, p. 127

${ }^{26}$ STELZER, J. Op. cit., p. 65.

${ }^{27}$ COSTA, José Augusto Fontoura. Multiplicidade jurídica e integração regional, p. 268

${ }^{28}$ RULLI JUNIOR, A. Op. cit., p. 74. O autor conclui: "A institucionalização do Mercosul passa necessariamente pela criação de um Parlamento e de um Tribunal de Justiça Supranacional que representam a segurança de investimentos na região e o desenvolvimento de uma cidadania capaz de formar um espaço de integração democratizado".

${ }^{29}$ ALMEIDA, E. A. P. de. Op. cit., p. 100.

${ }^{30}$ CAIROLI MARTINEZ, Milton. El papel de la justicia en el Mercosur, p. 226.

Revista da Faculdade de Direito da UFRGS, v. 20, Outubro/2001
Por fim, KLAES observa: "O aprimoramento do atual Sistema de Solução de Controvérsias, com a criação de um órgão judicial, se torna obrigatoriamente necessário para acompanhar e promover o crescimento do mercado interno e o aprimoramento da ordem jurídica do Mercosul. A instalação de um Tribuna Supranacional pode não ser o próximo passo, em razão do alto grau de maturidade política que uma instituição desse porte demanda, mas certamente será o passo seguinte. A experiência da CE é, nesse aspecto, uma oportunidade de aprendizado de valor inestimável, mas cabe aos Estados- Partes o condão de transformá-la em vantagem efetiva." ${ }^{11}$

Depreende-se que o Mercosul se apresenta como um modelo de integração intergovernamental, no qual uma decisão que implique nova postura do bloco deve ter o ne varietur de todos os governos. Sua estrutura atual requer a unanimidade dos Estados, com o que se torna mais difícil o avanço e o desenvolvimento normal do processo, uma vez que a ausência de consenso ocasiona o abandono, por algum tempo pelo menos, das metas encetadas. A União Européia, ao contrário, porta um paradigma de integração supranacional, em que as decisões emanam do órgão comunitário, que se encontra além e acima das competências estatais. Daí a importância do modelo europeu, cujo sucesso deve constituir-se em fator determinante para um processo de conscientização, não só dos Estados que compõem o bloco regional do Cone Sul, como também de toda a população mercosulista.

No paralelo entre essas duas formas de integração - a intergovernamental, no

${ }^{31}$ KLAES, Marianna Izabel Medeiros. Mercosul e tribunal supranacional: um dos pressupostos essenciais à efetiva integração, p. 368-369.

${ }^{32}$ URIARTE, Oscar Ermida. Mercosur y derecho laboral, p. 19.

${ }^{33}$ Idem, ibidem
Mercosul, e a supranacional, em adiantada fase na União Européia -, com evidente vantagem do modelo do Velho Mundo, devem ser buscados subsídios que permitam a aceleração do processo sul-americano. E esse caminho passa obrigatoriamente pela criação de um tribunal supranacional, o Tribunal de Justiça do é difícil a consolidação de uma comunidade sem seu órgão jurídico, de outro este organismo só ção comunitária, da qual é peça fundamental.

\section{A Aproximação das Legis- lações no Mercosul}

\subsection{A Aproximação nas Legislações}

Recorda URIARTE que "toda vez que se apresenta a questão da integração econômica regional surge, de maneira quase automática, a demanda de ou a pergunta sobre a harmonização ou a aproximação das legislações nacionais." 32

O mesmo autor uruguaio complementa: "Além das precisões das diversas técnicas a respeito (unificação, harmonização, aproximação), das vantagens e dos inconvenientes da convergência e de suas inevitáveis limitações em atenção às tendências provavelmente divergentes das negociações coletivas e as jurisprudências nacionais, o estado da opinião a respeito no Mercosul pareceria ser nem tanto nem tão pouco." 33

Ao abordar o tema da aproximação das legislações laborais no Mercosul, FERREIRA e Mercosul. Pode-se enfatizar que, se de um lado se justifica e fortalece no seio de uma institui- 
OLIVERA observam: "O nível mais profundo seria o da unificação e da uniformização das legislações. Este objetivo é de difícil aplicação prática, porque requer impor uma legislação coincidente para todos os países da área, o que só é possível lograr partindo-se de uma plataforma comum muito similar, hipótese que dificilmente ocorre"34.

Ainda na esteira das formas de convergência da legislação, reporte-se ao estudo de $B A B A C E$, para quem a uniformização "depende da profundidade com que se logre aproximar as legislações. Em um sentido, uniformizar é sinônimo da ação de convergir, e, em outro, é gênero de várias espécies." ${ }^{35} \mathrm{E}$ entre essas espécies, o mesmo autor refere a unificação, harmonização, aproximação e coordenação.

Entende-se que a unificação presume a uniformização completa das legislações, o que é viável em determinados institutos jurídicos, mas impensável em um segmento maior ou, menos ainda, em todo o ordenamento jurídico. ${ }^{36}$ Isso só seria possível quando a sociedade universal estivesse submetida a um só governo, ao mesmo poder de competência.

A harmonização seria a instituição de legislações em que houvesse um mínimo de divergências significativas entre seus postulados e as convergências fossem as mais amplas, facilitando a solução de lides que envolvessem esses ordenamentos jurídicos. ${ }^{37}$

Aproximação, por sua vez, deve ser entendida como a convergência de legislações em

${ }^{34}$ FERREIRA, Maria Carmen e OLIVERA, Julio Ramos. Mercosur: enfoque laboral, p. 37.

${ }^{35} \mathrm{BABACE}$, Héctor. Introducción al estudio de las relaciones laborales en los procesos de integración, p. 92.

${ }^{36}$ Idem, ibidem.

${ }^{37}$ Idem, ibidem.

${ }^{38}$ Idem, ibidem.

${ }^{39}$ Idem, ibidem

${ }^{40}$ PABST, Haroldo. Mercosul: direito da integração, p. 109.

${ }^{41}$ Idem, p. 34

Revista da Faculdade de Direito da UFRGS, v. 20, Outubro/2001 que ocorre uma busca de proximidade entre suas normas, limitada a determinado instituto ou a alguns deles. ${ }^{38}$

A coordenação, ainda na ótica de BABACE, seria "uma modalidade de convermedidas adotadas pelos Estados a nível interno, com base em políticas previamente coordenadas em instâncias regionais." 39

Na observação de PABST, "a transformação do mundo, em que nossos vizinhos não são mais os habitantes de uma cidade próxima mas os de cidades de países próximos, e em que a distância geográfica perde sentido, exige uma conformação de regras jurídicas básicas para estruturar os negócios inter-regionais, para dar segurança jurídica aos contratantes e para proteger a parte fraca da relação jurídica." ${ }^{40}$

Complementando essas assertivas, afirma o mesmo autor que a harmonização jurídica é o instrumento ideal para azeitar todo o processo de integração no próprio momento em que o mesmo ocorre.

Nesse sentido, PABST acentua que "o trabalho de colaboração internacional na busca da uniformização não deve limitar-se ao momento da adoção de uma norma única, mas deve ser permanente, com vistas principalmente à sua preservação"41

É ainda do mesmo autor esta observação: “A complementação de uniformização, através de um esforço harmonizador na área do digência pela qual as ações a promover implicam reito internacional privado, exatamente para aquelas relações jurídicas que, por razões culturais ou outras, não puderam ser objeto do processo de integração, é idéia que encontra corroboração em Ulmer (1992)." ${ }^{\text {42 }}$

Uma aproximação da legislação nos quatro países do Mercosul é uma imposição da fase que vive o movimento de integração regional encetado. Só ela será capaz de conduzir à formação de uma comunidade, aspiração maior vontade emblemática nesta quadra da história da integração. Sequer se poderá dizer que é uma utopia, por ser plenamente exeqüível entre povos já decididos a não mais viver estanques ou submetidos a situações de animosidades ou oposições.

Para VIANA SANTOS, significativamente: "É verdade que a construção de um Direito Comunitário para o Mercosul, entendido como o conjunto de normas vinculantes para instituições comunitárias e seus Estados-Membros, formando 'corpus harmônico', ainda passa por longo e laborioso caminho, cujo passo concreto inicial e a etapa ainda não vencida, prevista no Tratado de Assunção, de harmonização das legislações nacionais nas matérias pertinentes, encontra-se em curso" ${ }^{43}$.

Lembra JUCÁ que a possibilidade de um Direito Comunitário está condicionada à harmonização da legislação pertinente e lamenta que o processo para tal não está ocorrendo em qualquer dos Estados-membros do Mercosul, pelo menos com a dinâmica compatível e ante os interesses em jogo. ${ }^{44}$
A harmonização das legislações possibilitaria a pessoas que vivem sob bandeiras diferentes caminharem na mesma direção, encetando passos que sejam na direção comum, e que esses passos sejam imitados. Assim, esse movimento logo redundará na consolidação de um bloco econômico integrado, o Mercosul. Esse é, por certo, o futuro desejável por todos os que vivem e trabalham na futura comunidade do Cone Sul da América.

O artigo $1^{\circ}$ do Tratado de Assunção, em sua parte final, preconiza "o compromisso dos Estados-Partes de harmonizar suas legislações, nas áreas pertinentes, para lograr o fortalecimento do processo de integração". Lembra $R O Q U E$, entretanto, que "a resistência às mudanças já é uma tradição de nossas arcaicas estruturas jurídicas" ${ }^{45}$, manifestando uma antevisão dos obstáculos a serem vencidos na caminhada da aproximação das legislações no Mercosul em qualquer área da normatização jurídica, o que vai exigir redobrada atenção e empenho das populações interessadas, quai sejam, as pessoas dos quatro Estados-membros do bloco econômico regional do Cone Sul.

\subsection{A Aproximação nos Textos Constitucio-} nais

Por acreditar que a instituição de um sistema jurisdicional semelhante ao europeu pode ser o instrumento válido para a consolidação efetiva do Mercosul, lamenta KEMELMAJER $D E C A R L U C C I$ que "esta convicção não che-

${ }^{42}$ Idem, p. 42

${ }^{43}$ VIANA SANTOS, Antônio Carlos. Mercosul: espaços de integração e jurisdição, soberania e jurisdição supranacional, p. 25

${ }^{44}$ JUCÁ, J. F. Op. cit., 85. Indica esse autor desconhecer informações concretas sobre os trabalhos de harmonização e a existência de linhas de pesquisa sistemática em Universidades a respeito desse conhecimento do Direito Positivo em qualquer dos Estados do bloco regional.

${ }^{45}$ ROQUE, S. J. Op. cit., p. 177 
gou aos que detêm a decisão política de levar adiante a integração latino-americana." ${ }^{\prime 4}$

Recordando que independência integração são hoje termos necessariamente conciliáveis, ausente qualquer antinomia do passado, afirma GROS ESPIELL: "Um país é mais independente e mais soberano quando tem uma economia sadia em processo de expansão e crescimento. Um povo é mais livre quando sua vida se embasa em uma situação social que abre perspectivas de uma vida melhor." 47

OLIVAR JIMÉNEZ, por sua vez, ao estudar as particularidades do processo de integração no Mercosul, recorda que "para a doutrina integracionista, tanto européia como latino-americana, o elemento essencial que diferencia um processo integracionista da simples cooperação entre Estados é supranacionalidade." 48

Adverte SEITENFUS que, "sendo o Mercosul uma organização de natureza intergovernamental, a vigência das regras resultantes do funcionamento das instituições com poder decisório depende da internalização dessas decisões pelas ordens jurídicas internas dos Estados-partes." 49

Feitas tão oportunas e pertinentes alusões a estudiosos do fenômeno da integração e do próprio bloco econômico regional do Cone

Sul, engajados todos eles em trazer contribuições e luzes à nascente comunidade, é o momento de referir as grandes dificuldades geradas pela postura constitucional dominante nos países integrantes do Mercosul. Poder-se-ia afirmar que o empecilho maior provém da vontade dos constituintes de todos eles.

A rigor, a Constituição paraguaia, de 20 de junho de 1992, é a única, entre as Cartas Magnas dos Estados do Mercosul, que admite uma ordem jurídica supranacional, como se inscreve no artigo 145: "A República do Paraguai, em condições de igualdade com outros Estados, admite uma ordem jurídica supranacional que garanta a vigência dos direitos humanos, da paz, da justiça, da cooperação e do desenvolvimento político, econômico, social e cultural". Essa postura da Lex Legum paraguaia abre caminho para a inserção no ordenamento jurídico do País de norma emanada por um eventual legislador de Comunidade da qual o Paragua faça parte, como o Mercosul.

Exige a Norma Ápice paraguaia, é verdade, a aprovação dessa ordem supranacional pela maioria absoluta de cada uma das casas do Congresso.

Outrossim, a Constituição argentina, de $1^{\circ}$ de maio de $1853^{50}$, no artigo 75 , que trata das atribuições do Congresso Nacional, estabelece

${ }^{46}$ KEMELMAJER DE CARLUCCI, Aída. Integración y jurisdición, p. 202.

${ }^{47}$ GROS ESPIELL, Héctor. Naturaleza juridica del Tratado de Asunción y de sus protocolos, p. 244 ${ }^{48}$ OLIVAR JIMÉNEZ, Martha Lucía. La compreensión del concepto de derecho comunitario para una verdader integración en el cono sur, p. 128.

${ }^{49}$ SEITENFUS, Ricardo. Manual das organizaçōes internacionais, p. 221.

${ }^{50}$ A Argentina é o único dos países do Mercosul que teve ao longo de sua História apenas uma Constituição federal, sofrido substanciais reformas, sempre através de Cia $1^{\circ}$ de maio de 1853, que continua vigente, embora tenha 1994. ZAVALÍA, Ricardo de. Conpre através de Convenções Constituintes, em 1860, 1866, 1898, 1949, 1957 e A. Ramella, identificam a Carta Magna dén de la Nación Argentina, p. 5. Alguns autores argentinos, como Pablo A. Ramella, identificam a Carta Magna de seu país, como Constituição de 1853-1860, pela importância que vêem na primeira das grandes reformas. RAMELLA, P. A. Nacionalidad y ciudadania, p. 21.

Revista da Faculdade de Direito da UFRGS, v. 20, Outubro/2001 no inciso 24 que cabe ao mesmo "aprovar tratados de integração que deleguem competência e jurisdição a organizações supra-estatais em condições de reciprocidade e igualdade e que respeitem a ordem democrática e os direitos humanos".

Já as Cartas Magnas brasileira e uruguaia não fazem referência à instituição de uma ordem jurídica supranacional. Dão guarida, é verdade, aos movimentos de integração regional, prescrevendo a Constituição publicada em 1 de fevereiro de 1967 que a República Orienta do Uruguai "procurará a integração social e econômica dos Estados Latino-Americanos, especialmente no que se refere à defesa comum de seus produtos e matérias-primas" (art. $6^{\circ}$ ). A Constituição de 5 de outubro de 1988, no pará grafo único do artigo $4^{\circ}$, prescreve, por sua vez que "a República Federativa do Brasil buscará a integração econômica, política, social e cultural dos povos da América Latina, visando à formação de uma comunidade latino-americana de nações".

Em diligente trabalho sobre a supranacionalidade nas legislações constituci onais do Mercosul, KERBER recorda que o Brasil e o Uruguai não avançaram, desde a assinatura do Tratado de Assunção, no sentido de colocarem suas leis maiores nos patamares das da Argentina e Paraguai, no que se refere "à adoção do instituto da supranacionalidade, que demonstra as dificuldades que tal instituto apresenta ao bloco do Cone Sul." 51 E complementa, com propriedade, o mestre gaúcho: "Para essa etapa será necessário que as Constituições admitam expressamente a existência de um órgão judicial supranacional, que predomine sobre a estrutura dos respectivos poderes judiciários nacionais. Esses desafios a vencer encontram-se na ordem das preocupações dos meios jurídicos, políticos e diplomáti-

${ }^{51}$ KERBER, Gilberto. Mercosul e supranacionalidade: um estudo à luz das legislações constitucionais, p. 90. ${ }^{52}$ Idem, ibidem cos dos países envolvidos com a criação do Mercosul, para a adoção do instituto da supranacionalidade, que deve ser enfrentada com a revisão constitucional." 52

Depreende-se, pois, que os primeiros obstáculos a serem vencidos na busca da implantação de uma comunidade jurídica no Mercosul passam por um novo posicionamento constitucional dos Estados-membros do bloco, consubstanciada na cedência de parcela de soberania em favor de uma ordem jurídica que se estenda sobre todos eles. E essa postura a ser adotada, em especial, pelas leis maiores brasileira e uruguaia, é pressuposto para a consecução da almejada integração, a menos que se pretenda manter uma grande margem de discricionariedade nas condutas dos paísesmembros, o que pode redundar em um comprometimento do futuro do bloco.

\subsection{Todos Crescendo com a Integração}

A História é a mestra inexorável da razão. Também o é dos povos. Nela se encontram postulados e motivações para um encontro com o fim maior do ser humano: a felicidade. Sim, porque outro objetivo não tem o homem, em qualquer época ou lugar, senão a identificação com aquela situação de empatia consigo mesmo e harmonia com o meio, com o seu semelhante e com os outros seres que o cercam, vivos ou inanimados.

A infindável sucessão de desencontros entre os povos, de que é o mais pungente exemplo a guerra, nada mais reflete do que um anseio de ser feliz. Nessas situações se entende que a busca da felicidade redundou em um domínio do vencedor, que o comemorou sobre ruínas, com a destruição daquilo que também lhe seria necessário e útil. 
São bem atuais as observações, feitas em 1984, por SILVA: "É indubitável que na sociedade internacional do século $\mathrm{XX}$ a idéia do isolamento dos Estados é utópica e irrealizável. O processo tecnológico derivado da Revolução Industrial, a dinâmica e mobilidade social, progresso individual e o desenvolvimento dos povos impõem a necessidade de integração e complementação sobre bases políticas, culturais e econômico-sociais." ${ }^{53}$

Busque-se o entendimento de JUCÁ para quem o modo de produção imposto no interregno entre a Modernidade e a PósModernidade "com a cultura da velocidade de obsolescência e as idéias de instantaneidade descartabilidade, que inclui o processo produtivo e o sistema econômico, ensejam enorme exclusão humana, e legiões inteiras, em todo os países e sistemas são colhidas pelo desemprego, subemprego, falta de condições de sobrevivência, gerando massas de excluídos, de desassistidos lançados à própria sorte, os quais os Estados nacionais são incapazes de atender. com os mecanismos disponíveis e pela falta de recursos." ${ }^{54}$

No âmago do processo da globalização em marcha e o contraponto da instituição de blocos de integração econômica regional, em que se vive, somadas a tantas outras mudanças, assim observa OLIVEIRA: "Nosso planeta, antes circundado por grandes e desconhecidas distâncias, parece que agora encolheu, tornou-se virtual, face a uma rede instantânea de fácil comunicação de massa somada ao avanço acelerado da revolução tecnológica. Na rea-

lidade, não há atividades que possam escapar dos efeitos da globalização do capitalismo, pois o mundo, atualmente, se apresenta sem fronteiras, com sua economia e cultura mundializadas e onde as corporações transnacionais, cosmopolitas, descentralizadas e independentes dos Estados, operam sem nacionalidades, sob o comando do poderoso processo global: nova divisão internacional do trabalho, mudança total nos fluxos comerciais internos e externos sob diferente dinâmica de regulação financeira, reprodução ampliada do capital em escala global, maximização da produtividade e de seu lucro, competitividade entre as empresas transnacionais na acirrada arena da guerra comercial frente à disputa do controle dos principais mercados do mundo." 55

Os tempos presentes são também de interdependências, de um lado, e de privatização, liberalização, competitividade e desregulamentação, de outro, o que COVAS chamou de regime da ditadura globalitária. ${ }^{56}$ Afirma o mestre português: "Os territórios regionais politicamente constituídos reagem acaloradamente a esta mercantilização do seu território sobrecarregando os poderes centrais com reivindicações sucessivas de compensação e transferência de recursos." 57 Isso coloca em tensão permanente o regime democrático nos planos internacional, supranacional e nacional.

Não se cogita ignorar as pontes invisíveis, mas concretas, que tentam aproximar os indivíduos em todas as dimensões geográficas. O homem, em qualquer Continente, mesmo no mais afastado recôndito do planeta, está, de uma

${ }^{53}$ SILVA, Hector Ramon. La comunidad internacional, p. 108.

${ }^{54}$ JUCÁ, Francisco Pedro. Possibilidades de um parlamento latino-americano vinculado ao Mercosul, p. 49 Enfatiza ainda esse autor: "O desafio da contemporaneidade é enfrentar, adequada e eficientemente, o p. 49. entre incluídos e excluídos, partícipes do processo e marginalizados, o tue requada e eficientemente, o abismo Ibidem.

${ }^{55}$ OLIVEIRA, Odete Maria de. União Européia: processos de integração e mutação, p. 23

${ }^{56}$ COVAS, A. Op. cit., p. 7

${ }^{57}$ Idem, p. 7-8.

Revista da Faculdade de Direito da UFRGS, v. 20, Outubro/200I maneira ou de outra, preso ao seu semelhante, ainda que dele afastado por milhares de quilômetros, por um liame de interdependência. Se a vinculação humana, psicológica, emocional ou moral não conseguiu aproximá-lo, no passado, às injunções do presente - sejam de que ordem forem - hoje o une e o torna convivente com a assimetria imposta pelas injunções do mercado econômico mundializado.

O Mercosul tem ensejado a busca incessante da integração desejada pelos povos dos Estados-membros, o que permite antever avanços no seu porvir. ALMEIDA lembra que a prática diplomática tem levado a consultas políticas entre os quatro Estados, sobretudo entre Brasil e Argentina, incluindo os setores militares. Já ocorreram encontros dos EstadosMaiores das Forças Armadas nacionais brasileiras e argentinas, reduzindo ao mínimo, a proporções insignificantes, os riscos de uma instabilidade político-militar nas relações entre os dois países. Com isso, a possibilidade de guerra entre Brasil e Argentina, no passado uma hipótese previsível, é cada vez mais remota quase impossível. ${ }^{58}$ Trata-se, enfatize-se, de algo inimaginável, há apenas uma década, e que já permite vislumbrar uma política de segurança comum para o bloco regional.

O próprio ALMEIDA destaca, entretanto, que o processo de integração, por si só, não vai resolver todos os dilemas do desenvolvimento. Ele é simplesmente "uma poderosa alavanca e um indutor do aperfeiçoamento das estruturas produtivas no âmbito empresarial, das condições de concorrência em nível macroeconômico e do grau de bem-estar do consumidor final." 59

${ }^{58}$ ALMEIDA, P. R. O Mercosul no contexto global, p. 131.

${ }^{59}$ Idem, p. 116

${ }^{60}$ GENRO, Tarso. O mundo globalizado e o estado necessário, p. 33

${ }^{61}$ Idem, p. 36. Para esse autor, tal processo não é impossível ou utópico, bastando integrar-se politicamente as sociedades, através de diferentes formas de Conselhos, que envolvam inclusive cidades e regiões fronteiriças e com afirmações de suas personalidades culturais.

Revista da Faculdade de Direito da UFRGS, v. 20, Outubro/2001

As reformas trazidas pela globalização econômica, que tanto têm diminuído o tamanho do Estado, deveriam oferecer a compensação de torná-lo mais democrático, como asseverou GENRO, desde que "o mesmo seja controlado por uma sociedade civil exigente, dotada de instituições políticas e meios tecnológicos para tal." ${ }^{60}$ Para o mesmo autor, a integração regional e seus consectários requerem "a emergência de uma nova concepção de cidadania, ou seja, a emergência de uma cidadania transnacional, onde o local, o regional e o nacional integrem-se em diferentes formas de convívio econômico e cultural: para que, assim, a internacionalização da economia seja amparada no reconhecimento das identidades e, ao mesmo tempo, pelo enriquecimento recíproco das culturas participantes." 61

A realidade está indicando que o caminho buscado, o da integração dos povos do Mercosul em um mercado comum, tem-se mostrado exequível, superada, em sua maior parte, livre comércio, e encetada a fase de união aduaneira.

Só o futuro responderá questionamentos que se levantam sobre o bloco regional do Cone Sul, com o que perdurarão os sonhos que povoam as consciências das populações engajadas no processo. Todas as pessoas que aí vivem ou trabalham, como já referido, alme"a constituição de um bloco econômico único, com o surgimento de políticas comuns em setores como a atividade agrícola, industri, de transportes' e de comunicações. E mesmo uma política de proteção ao consumidor e ao 
meio-ambiente, tão necessárias para a fraternal convivência entre os povos." 62

Verifica-se uma salutar preocupação com o social no Mercosul, especialmente na área da legislação trabalhista - o direito laboral, termo muito em voga, pelos autores hispano-americanos -, envolvendo a organização sindical, as relações individuais e coletivas de trabalho, os planos de seguridade social, a previdência social, as negociações coletivas e a livre circulação de trabalhadores. ${ }^{63}$

Como é facilmente compreensível, a abor dagem da circulação de pessoas entre os países do bloco regional do Cone Sul, aí incluído os trabalhadores, tem uma correlação muito próxima com a adoção do espírito comunitário. $O$ obreiro que chega de seu país não se dirigiu um Estado estrangeiro, mas foi de uma parte de um bloco econômico regional a outra, na qual deve encontrar a mesma norma jurídica de seu país de origem.

Os blocos regionais que estão buscando a integração de Estados têm sua gênese no fator econômico e comercial. Seguem, normalmente, um modelo que começa com uma zona de livre comércio e chega à etapa do chamado mercado comum. Exceção feita ao paradigma d União Européia, que pretende atingir a fase completa de União Política.

Não se pode imaginar que o Mercosul tenha limites na sua caminhada de busca da integração de todas as gentes dos países engajados. Exsurge a necessidade de uma adaptação e convergência na lei fundamental de cada um dos Estados componentes do bloco, permitindo que o espírito de comunidade, o sentimento de que sua população é uma só, com objetivos, sonhos e aspirações comuns, passe

${ }^{62}$ DEL'OLMO, F. S. Op. cit., p. 161.

${ }^{63}$ Sobre o tema, é por demais oportuna a leitura da excelente obra de Augusto Jaeger Junior, Mercosul e a livre circulação de pessoas, resultado de bem elaborada dissertação de Mestrado na UFSC, em 1999.

Revista da Faculdade de Direito da UFRGS, v. 20, Outubro/2001 ção de todas as lides jurídicas que provenham de uma norma do Direito interno quando em conflito com a prescrição emanada do legislador comunitário.

Os complexos desafios que se antepõem na caminhada do Mercosul não devem ser vistos como obstáculos intransponíveis, mas como estágios inerentes aos movimentos integracionistas. A longa jornada em que se constituem essas iniciativas comporta etapas que necessitam de muita vontade política dos Estados e engajamento das populações envolvidas no processo. Se esses dois pressupostos se fizerem presentes não se deve duvidar que brasileiros, argentinos, paraguaios e uruguaios - assim como chilenos, bolivianos e venezuelanos, na complementação projetada do Mercosul - gozarão em tempos vindouros da saudável prerrogativa de viver em uma comunidade que será para eles a grande pátria de todos.

\section{Considerações finais}

Vive o Mercosul uma situação de primeira fase de um processo de integração, a zona de livre comércio, quase implementada. O segundo estágio - o da união aduaneira - desenvolve-se em ritmo lento, apesar de já estabelecida a tarifa externa comum entre Brasil, Argentina, Uruguai e Paraguai, preparando-se, de certa forma e em alguns aspectos, as perspectivas para a fase de mercado comum, a rigor o objetivo-título da instituição do bloco.

Na busca da integração do Cone Sul, palco de movimentos de aproximação no passado, quais sejam a Associação Latino-Americana de Livre Comércio (ALALC) e a Associa- a falar mais alto no encaminhamento da solu- ção Latino-Americana de Integração (ALADI), entre outros, o Mercosul palmilha caminho mai entro, reavivando esperanças e criando expectativas favoráveis à integração que se propectativa.

Deve-se lembrar que a ALALC e a ALADI se sucederam no pequeno interregno de duas décadas, sem apresentar resultados palpáveis. E se considere que a primeira delas portava, modestamente, no próprio título designativo, a condição de associação de livre comércio, contentando-se, assim, com a primeicomércio, contentando-se, de qualquer processo de integração.

Resultado de pretensões seculares de próceres sul-americanos, o Mercosul atinge seus primeiros objetivos e busca conquistar seu espaço, aproximar os governantes de países tradicionalmente divergentes e portadores de dificuldades geradas por incompreensões que, em bão se perdendo no tempo, tentando trazer reais benefícios para as populações.

Os desafios de seus problemas e dificuldades são enormes. A superação vem sendo buscada e a cada dia se evidencia mais próxima. Sente-se, no desenho do Mercosul, um clima de obstinado desejo de integração dos povos da América Latina, seguindo o exemplo invocado da União Européia.

Urge passar-se ousadamente do Mercosul real para o Mercosul ideal. O que existe é ainda um simulacro do que sempre pretenderam os empreendedores e seus povos. Não cabe lamentar tempo perdido, oportunidades desperdiçadas, tarefas não cumpridas, etapas relegadas. Há que se criar o espírito mercosulista no seio das massas populares. Formar na população de toda a área a empatia da integração, o anseio de aproximação e de busca da união, sem questionar dificuldades. O mundo está repleto de exemplos de povos que buscaram nas vicissitudes e nas intempéries da História a chama que os unificou na persecução de ideais capazes de torná-los mais cônscios de suas potencialidades, mais ricos, mais felizes e mais orgulhosos de seu destino.

Deve brotar no seio de cada rincão do Mercosul, de fala portuguesa ou espanhola, a cobrança para que os legisladores apressem a adaptação dos textos constitucionais e legais, tornando possível a almejada comunidade mercosulista. Essa não se tornará realidade enquanto um excessivo ranço de soberania estiver arraigado entre as pessoas e entre seus representantes. Um novo paradigma deve ressaltar-se, olvidando o absolutismo da soberania medieval, na qual o Estado se confundia com o monarca.

O presente ensaio propõe o engajamento na busca dessa aproximação legislativa. Considera-se que ela é viável, a par de ser desejável pelas pessoas que vivem e trabalham nos quatro Estados-membros do bloco econômico regional do Cone Sul.

Há que se partir para a sua efetiva implantação. Não há melindres que devam ser evitados, nem ressentimentos ou animosidades que tornem os indivíduos distantes apenas por viver em outro Estado de um mesmo bloco.

Não se deve imaginar que o fim do segundo milênio - fase da História de que se está tendo o privilégio de vivenciar e participar seja apenas o suceder de um ciclo da longa cruzada dos povos pelo mundo, mas um período que pode e deve ser marcado por conquistas grandiosas, a maior das quais, com certeza, seria entendimento e a compreensão entre as pessoas de um bloco, de um megabloco, do mundo globalizado por fim, no sentido de tornar possível o seu sonho mais elevado e acalentado em todas as épocas, a celebração do franco entendimento entre todas as pessoas.

Como se observou no estudo, não se trata de utopia impraticável a convergência nas legislacões sobre a supranacionalidade e a instituição de uma só comunidade nos Estados que formam o bloco econômico regional do ConeSul. 
Impõe-se apenas que cada Estado-membro adapte a sua Constituição, inserindo no supremo texto legislativo a possibilidade de integração do país em um organismo supra-estatal, a exemplo da atual Carta Magna do Paraguai. Como se viu, o caminho se encontra nos próprios textos maiores analisados, nos quais há um vislumbre de aceitação da integração, ainda limitado, mas que necessita ser ampliado com a admissão da plena inserção do país no organismo comunitário, privilegiando as normas supranacionais sobre as de seu direito interno.

\section{Bibliografia}

ALMEIDA, Elizabeth Accioly Pinto de. Mercosul \& União Européia: estruturajurídico-institucional. Curitiba: Juruá, 1996. 160 p

ALMEIDA, Paulo Roberto de. O Mercosul no contex-

to regional e internacional. São Paulo: Aduane ras, 1993. $204 \mathrm{p}$.

TOS O Mercosul no contexto global. In: BASTOS, Celso Ribeiro e FINKELSTEIN, Cláudio (Coordenadores). Mercosul: liçóes do período de transitoriedade. São Paulo: Instituto Brasileiro de Direito Constitucional, 1998. p. 109-135.

reito Constitucional, 1998. p. 109-135.
ARAÚJO, Luis Ivani de Amorim. Direito internacional público. 9. ed. Rio de Janeiro: Forense, 1995. $364 \mathrm{p}$.

BABACE, Héctor. Introducción al estudio de las relaciones laborales en los procesos de integración. Montevidéu: Fundação de Cultura Universitária, 1998. $169 \mathrm{p}$.

BAHIA, Saulo José Casali. A supranacionalidade no Mercosul. In: BASTOS, Celso Ribeiro e FINKELSTEIN, Cláudio (Coordenadores) Mercosul: lições do periodo de transitoriedade. São Paulo: Instituto Brasileiro de Direito Constitucional, 1998. p. 193-208.

BASALDÚA, Ricardo Xavier. Mercosur y derecho de integación. Buenos Aires: Abeledo-Perrot, 1999. $910 \mathrm{p}$.

BERTOLOTTI, Silvina Barón Knoll de. Administración y gobierno del Mercosur. Buenos Aires: Depalma, 1997. $201 \mathrm{p}$.

BORCHARDT, Klaus Dieter. Oabc do direito comunitário. 3. ed. Luxemburgo: Serviço das Publicações Oficiais das Comunidades Europeias, $1991.50 \mathrm{p}$.
CAIROLI MARTINEZ, Milton. El papel de la justicia en el Mercosur. In: Revista da Faculdade de Direito das Faculdades Metropolitaculdade de DiPaulo, a. X. n. 16, jul/dez 1996. p. 217-226. Säo

CAVARZERE, Thelma Thais. Direito internacional pessoa humana: a circulaceito internacional da pessoa humana: a circulação internacional de pessoas. Rio de Janeiro: Renovar, 1995. 275 p.

CHIARELLI, Carlos Alberto Gomes. (Coordenador). Temas de integração com enfoques no Mercosul. v. I. São Paulo: LTr, 1997.

CONSTITUIÇÃO da República Federativa do Brasil. 21. ed. São Paulo: Saraiva, 1999. 267p.

CONSTITUCIÓN de la Nación Argentina. Buenos Aires: Editorial Universidad, 1985. 257p.

CONSTITUCIÓN de la República del Paraguay. Asunción: Fides, 1993. 98 p.

COSTA, José Augusto Fontoura. Multiplicidade jurídica e integração regional. In: PIMENTEL, Luiz Otávio (Organizador). Mercosul no cenário internacional: direito e sociedade. v. I. Curitiba: Juruá 1998. p. 263-270.

COVAS, Antônio. A União Européia. Oeiras: Celta, 1997. $142 \mathrm{p}$.

DELGADO, Maria Isabel Lirola. Libre circulación de personas y Unión Europea. Madrid: Fundación Universidad-Empresa, 1994. $318 \mathrm{p}$.

DEL'OLMO, Florisbal de Souza. Direito internacional privado: abordagens fundamentais, le gislação, jurisprudência. Rio de Janeiro: Forense, 1999. 259 p.

luz do O Mercosul e a nacionalidade: estudo à luz do direito internacional. Rio de Janeiro: Forense, 2001. $226 \mathrm{p}$.

ESTRELLA FARIA, José Ângelo. O Mercosul: princípios, finalidade e alcance do Tratado de Assunção. Brasília: MRE/SGIE/NAT, 1993. 193 p.

RREIRA, Maria Carmen e OLIVEIRA, Julio Ramos. Las relaciones laborales en el Mercosur. Montevidéu: Fundação de Cultura Universitária, 1997. 254 p.

. Mercosur: enfoque laboral. Montevidéu: Fundação de Cultura Universitária, 1994. 123 p. GENRO, Tarso. O mundo globalizado e o estado necessário. In: Revista da Faculdade de Direito de Cruz Alta: Lato Sensu. Cruz Alta: Unicruz, Departamento de Ciências Jurídicas, v. 1, a. 3, dez. 1997. p. 31-40.

GRASS, Gunter. Não amor, mas tolerância. In: Zero Hora: Cultura. Porto Alegre: 24.06 .2000 , p. $4-5$.

ROS ESPIELL, Héctor. Naturaleza jurídica del Tratado de Asunción y de sus protocolos. In: CHIARELLI, Carlos Alberto Gomes (Coordenador). Temas de integração com enfoques Mercosul. v. I. São Paulo: LTr, 1997. p. 240-267.
HUSEK, Carlos Roberto. Elementos de direito intemacional público. São Paulo: Malheiros, 1995. $203 \mathrm{p}$

JAEGER JUNIOR, Augusto. Mercosul e a livre circulação de pessoas. São Paulo: LTr, 2000. $190 \mathrm{p}$.

JUCÁ, Francisco Pedro. Possibilidades de um parlamento latino-americano vinculado ao Mercosul. In: Revista da Faculdade de Direito das Faculdades Metropolitanas Unidas. São Paulo, a. X, n. 16 , jul/dez 1996. p. 39-92.

KEMELMAJER DE CARLUCCI, Aída. Integración y jurisdición. In: Revista da Faculdade de Direito das Faculdades Metropolitanas Unidas. São Paulo, a. X, n. 16, jul/dez 1996. p. 195-202.

KERBER, Gilberto. Mercosul e supranacionalidade um estudo à luz das legislações constitucionais. Florianópolis: Dissertação de Mestrado em Direito UFSC, 2000. 123p.

KLAES, Marianna Izabel Medeiros. Mercosul e tribunal supranacional: um dos pressupostos essenciais à efetiva integração. In: PIMENTEL, Luiz Otávio (Organizador). Mercosul no cenário internacional: direito e sociedade. v. I. Curitiba: Juruá, 1998 p. $359-370$.

LA NUEVA Constitución Nacional. Assunção: Noticias El Diario rpc, 1992. $58 \mathrm{p}$

LOBO, Maria Teresa Cárcomo. Ordenamento jurídico comunitário. Belo Horizonte: Del Rey, 1997. 358 p.

LORENTZ, Adriane Cláudia Melo. Supranacionalidade no Mercosul. Curitiba: Juruá, 2001. 126 p.

LOURO FIGUERAS, José Geraldo. Constitución de la República Oriental del Uruguay. Montevidéu: Comunidad del Sur, 1967.221 p.

MATHIEU, Jean-Luc. L'Union Européenne. 2. ed. Paris: Presses Universitaires de France, 1996. 128 p.

MIDÓN, Mario A. R. Derecho de la integración. Bueno Aires: Rubinzal-Culzoni, $1998.463 \mathrm{p}$

OLIVAR JIMÉNEZ, Martha Lucía. La compreensión del concepto de derecho comunitario para una in da Faculdade de Direito das Faculdades Metropolitanas Unidas. São Paulo, a. X, n. 16, jul/dez politanas Unidas.

OLIVEIRA, Odete Maria de. A integração bilatera Brasil-Argentina: tecnologia nuclear e Mercosul. In: Revista Brasileira de Política Internacional. Brasília, v. 41, n. 1, 1998. p. 5-23.

.Integração nuclear Brasil-Argentina: uma estratégia compartilhada. Florianópolis: UFSC 1996.

Relações internacionais: breves apontamento e contextualização. In OLIVEIRA, Odete Maria de. (Coordenadora). Relações internacionais a globalização. Ijuí: Editora Unijuí, 1998. p. 15-65.
União Européia: processos de integração e mutação. Curitiba: Juruá, $1999.486 \mathrm{p}$

PABST, Haroldo. Mercosul: direito da integração. Rio de Janeiro: Forense, 1998. 278 p.

APPALARDOZALDÍVAR, Conrado. (Recopilación). Paraguay: itinerário constitucional. 6. ed. Assunção: Intercontinental, $1997.317 \mathrm{p}$.

PELLEGRINI, Miguel A. Ortiz Pellegrini e al. (Organizadores). Constitución de la Nación-República Argentina. Cordoba: Marcos Erner, 1994. $185 \mathrm{p}$.

PÉREZ PÉREZ, Alberto. Constitución de 1967 de la República Oriental del Uruguay Actualizada (1997). 3. ed. Montevidéu: Fundação de Cultura Universitária, 1998. 180p.

- Constitución de 1967 de la República Oriental del Uruguay concordada y anotada. v. I. 2 . ed. Montevidéu: Fundação de Cultura Universitária, 1994. $463 \mathrm{p}$.

PIMENTEL, Luiz Otávio (Organizador). Mercosul no cenário internacional: direito e sociedade. v. I. Curitiba: Juruá, 1998. 527 p.

RAMELlA, Pablo A. Nacionalidad y ciudadanía. Buenos Aires: Depalma, 1978. 117p.

RECKZIEGEL, Ana Luiza Gobbi Setti. O pacto ABC: as relações Brasil-Argentina na década de 50. Passo Fundo: Ediupf, 1996. 181 p.

REY PAZ, Vânia Beatriz. Mercosul: legislações sindicais (im)possibilidade de harmonização. Curitiba: Juruá, 1999.

ROQUE, Sebastião José. Direito internacional público. São Paulo: Hemus, 1997. 272p.

ROVAN, Joseph. Como tornar-se cidadão da Europa: primeiro os deveres, depois os direitos. Trad. J. Freitas e Silva. Lisboa: Publicações Dom Quixote, 1993. $217 \mathrm{p}$.

RULLI JUNIOR, Antonio. MERCOSUL: o direito comunitário e a garantia de investimentos e cidadania In: Revista da culdades Metropolitanas Unidas. São Paulo, a. XII, n. 20 , 1998. p. $60-78$.

SABSAY, Daniel Alberto e ONAINDIA, José Miguel. La constitución de los argentinos. 4.ed. Buenos Aires: Errepar, 1998. 445 p.

SANTOS, Ricardo Soares Stersi. Mercosul e arbitragem internacional comercial: aspectos relevantes e algumas possibilidades. Belo Horizonte: Del Rey, 1998

SARMIENTO GARCÍA, Jorge H. e FARRANDO, Ismael. "rocesos de integración y Mercosur. Buenos Aires: Depalma, 1993. 120 p.

SEITENFUS, Ricardo. Manual das organizações internacionais. Porto Alegre: Livraria do Advogado, $1997.352 \mathrm{p}$ 
SILVA, Hector R. La comunidad internacional. Buenos Aires: Depalma, 1984. $189 \mathrm{p}$

SILVA ALONSO, Ramón. Derecho internacional privado. 5. ed. Assunção: Intercontinental, 1999. 518 p.

SILVA, Roberto Luiz. Direito comunitário e da integração. Porto Alegre: Síntese, 1999. $192 \mathrm{p}$.

SOARES, Esther Bueno. Mercosul: desenvolvime to histórico. São Paulo: Oliveira Mendes, 1997. $137 \mathrm{p}$.

SOARES, Orlando. Comentários à Constituição da República Federativa do Brasil. 9. ed. Rio de Janeiro: Forense, 1998. $896 \mathrm{p}$

ODER, José. A União Européia São Leopoldo: Unisinos, $1995.183 \mathrm{p}$.

STELZER, Joana. Integração européia: dimensão supranacional. Florianópolis: Dissertação de Mestrado em Direito UFSC, 1998. 212

RATADO de Amsterdam. Luxemburgo: Serviço das Publicações Oficiais da Comunidades Europeias, 1997. $144 \mathrm{p}$

URIARTE, Oscar Ermida. Mercosur y derecho laboral. Montevidéu: Fundação de Cultura Universitária, 1996. $89 \mathrm{p}$

VALLEEE, Charles. O direito das comunidades européias. Trad. Eduardo Saló. Lisboa: Editorial Nottcias, $1983.119 \mathrm{p}$.
VERSÃO compilada do tratado da União Européia Luxemburgo: Serviço das Publicações Oficiais da Com

de inANTos, Antônio Carlos. Mercosul: espaço de integração e jurisdição, soberania e jurisdiçãa supranacional. In. Revista da Faculdade de Dire to das Faculdades Metropolitanas Unidas. São Paulo, a. X, n. 17, jul/dez 1996. p. 19-32.

Mecos Tribunal de justiça supranacional do Mercosul. In: Revista da Faculdade de Direito das Faculdades Metropolitanas Unidas. São Paulo, a. X, n. 16, jul/dez 1996. p. 23-37.

IGNALI, Heber Arbuet. Soberanía e integración. In: CHIARELLI, Carlos Alberto Gomes (Coordenador). Temas de integração com enfoques no Mercosul. v. I. São Paulo: LTr, 1997, p. 84-104.

WOLKMER, Antônio Carlos. Integração e direito comunitário latino-americano. In: PIMENTEL, Luiz Otávio (Organizador). Mercosul no cenário internacional: direito e sociedade. v. I. Curitiba: Juruá, 1998. p. 43-54.

ZAVALÍA, Ricardo de. Constitución de la Nación Argentina. Buenos Aires: Zavalía S. A., 1998. 519 p.

\title{
Construcción social del derecho: aproximaciones al debate del siglo XXI
}

\author{
Graciela Lovece
}

\section{Introducción}

(ר) ada estructura social tiene caracterísiticas distintivas, cada una de ellas posee una realidad; y esta realidad; es construída socialmente.

El afuera de cualquier observador, in vestigador, legislador juez es objetivo respecto de ese sujeto como individuo atomizado, pero no como ser humano ya que lo objetivo no existe como tal; pues la supuesta realidad es Construída por otros. y cada sociedad adopt una realidad diferenciada. ${ }^{1}$

Las claves son entonces realidad y su conocimiento; pudiendo definirse la realidad como una cualidad propia de los fenómenos que reconocemos como independientes de nuestra volición y los que no podemos impedir que existan.

Por otro lado el conocimiento es la certidumbre de que estos fenómenos son reales y que poseen características específicas y que pueden ser aprehendidos. ${ }^{2}$

Asi por ejemplo un hombre común de la calle cree que posee libre albedrío y que en virtud de esa libertad es responsable de sus actos, ahora bien también conoce que los menores no gozan de esa libertad reconociendo para estos una realidad diferente.

Este mismo fenómeno de la realidad si es analizado por un filósofo se preguntará que es la libertad? Que es la responsabilidad? Cuales son sus límites? etc.

Un sociólogo en cambio indagará por qué la noción de libertad ha llegado a darse por establecida en algunas sociedades y en otras no?; cömo alguna de estas sociedades conservan esta realidad? y lo que resulta más interesante aún es saber como esa realidad puede desaparecer para un individuo o para una colectividad entera. $?^{3}$

Esa construcción de la realidad resulta de la existencia de formas organizativas y/o institucionales diversas vrg. empresas,

${ }^{1}$ Bordieu, Pierre: "Los usos sociales de la Ciencia” pág. 109. Ed INRA Bs. As 2000

2 Berger. Peter, Luckmann, Thomas: “La Construcción Social de la Realidad” pág. 13 Ed Amorrortu Avellaneda 1999.

${ }^{3}$ Berger, Peter; Luckmana, Thomas: "La Construcción Social de la Realidad” pág 14 Ed Amorrortu Avellaneda 1999. 